$5|25|:$

International Students' Federation

THe account given in the first issue of the British Medical Stud nt ', Arnal of events which led to the formation of the International Students' Federation and of. We rebirth of the Czech universities is grint put in spiring reading. On November 17, 1939, the ofmans closed the Charles University at Prague, shot nine heads of the student organisations and sent many male students either to concentration camps or to enforced labour in Germany. In memory of these and other early sacrifices, this day was celebrated in Britain and elsewhere as International Students' Day, and by the end of the War it was being celebrated all over the world as a day of remembrance and renewed resolve. The Czech students in exile in Britain wished that the first peace-time celebration of this day should be held in Prague, and, in November 1945, they invited students from fifty-one countries to be their guests. Some four hundred students accepted this invitation, and the article pays a tribute to the Czech studentsand, indeed, to the whole population-for their reception of so many visitors only six months after the liberation of the country. Working in cooperation with the National Union of Students, a preparatory committee had already drafted the constitution of the new International Students' Federation. Co-operation with the World Federation of Democratic Youth and with the World Youth Conference held in London in November 1945 ensured further progress. The Prague Congress in 1945, an account of which is given, expressed the hope that the new International Students' Federation would be finally $f$ instituted during the summer of this year.

\section{Working in Wood}

UNDER the ausn $\mathrm{S}$ the Department of Scientific and Industrial Woarch the Forest Products Research Laboratory pas issued a "Handbook of Woodcutting" (H.M. Seatilnery Office, 1946. Pp. 44. 9d. net) by $P$. Harrs. Owing to the numerous requests received af th, Laboratory for help in sawmilling and wooddrkikg problems, it became obvious that a handbook on correct technique was required. The present publication is designed as a handy reference book, with a scientific background, from which the mathematical aspects of the subject have been omitted, with the exception of certain simple formulæ. The handbook contains detailed information and recommendations relating to the various forms of sawing and to planing, moulding, tenoning, mortizing, boring and turning operations. Diagrams and tables are added where necessary. Now that the area of forests is growing so convincingly in Great Britain, it is to be hoped that the time-honoured forms of handling wood by hand turnery, bending, shaving, toy carving and so forth, for all of which certain types of tools are required and must be kept in perfect condition, will be kept alive or brought backespecially hand earving by the new forest populations, as so cegfmonly to be found in parts of Europe.

\section{The European Chafer in America}

THE Corndy hiversity Agrieultural Experiment Station has (ssued Memoir 266 on the "External Morpholog of Amphimallon Majalis, the European Cogk hqter', by F. H. Butt (University Ithaca, New Yor December 1944). The European chafer, it is of considerable interest to hear, is a very modern introduced species, first reported in Wayne Coupaty, New York, in 1942, as being very destructive to

\section{October 12, 1946 vol. 158}

lawns and to pasture lands in this region, the greatest destruction being done during its larval stages. The insect was closely studied in its three larval stages, and a life-history was published in 1943. The paper describes the external morphology of these various stages of the insect, with thirteen excellent plates. The generic name Amphimallon is attributed to Latreille. Most entomologists and foresters of the older generations will be better acquainted with the insect under its old-time name of Melolontha vulgaris, a well-known pest in European continental hardwood forests, especially oak, as is the case in Great Britain.

\section{$X$-Ray Analysis in the Steel Industry}

The X-ray Analysis Group of the Institute of Physics has arranged a meeting to take place in the conference hall the Royal Victoria Hotel, Sheffield, on November 8 and 9 . On November 8, Dr. A. J. Bradley wil speak on "The Intensity Relations of Debye-Sh nerrer Powder Diffraction Lines", and Dr. W/A. Wood on "The Application of X-rays to the Study of Stresses in Metals". The morning session on November 9 will include three papers, one by Prof. G. I. Finch on "The Surface Structure of Metals", one by Mr. H. J. Goldschmidt on "An X-ray Investigation of Electro-Deposited Chromium", and one by Dr. A. H. Jay on "Some Successes and Failures in the Application of X-rays to Industrial Problems". The meeting is open to all without charge; those who wish to take part in the discussions following these papers should notify Mr. F. A. Bannister (Hon. Sec.), Department of Mineralogy, British Museum (Natural History), London, S.W.7.

\section{Racemic Acid}

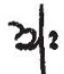

IN an interesting waper recently available in Britain, Prof. Pelpine (Bull. Soc. Chim., 8, 463; 1941) gives sph historical facts relating to the discover Neemic acid, which supplement the note by P.t. A. Findlay (Nature, 140, $22 ; 1937$ ). TrA pid was obtained accidentally in the crystallizatid of tartaric acid in a factory in Thann, Alsace, belonging to Kestner, which seems to have ceased operations about 1822 , and is first mentioned by John in his "Handwörterbuch der allgemeinen Chemie" in 1819. The name 'racemic acid' was first used by Gay-Lussac in his lectures, notes of which were published in 1828, and he showed that it had the same composition as tartaric acid. Berzelius, in 1830, in discussing this fact, first used the word 'isomer'. The further history of the acid, in particular in the work of Pasteur (who was the first to use the name 'racemic' in general), is given in the article.

\section{Journal of the British Grassland Society b|:}

THE first number of the Journal of the British Grassland Society 15 s now been issued. The price of Volume $1_{0}$ (Nogir and 2), 1946, is $10 s$, and application for p.m hase should be made to the Secretary, British Grafland Society, Agricultural Research Byilding Penglais, Aberystwyth. The volume opens wit $\mathrm{a}_{\mathrm{a}}$ foreword by Sir George Stapledon and also includes his presidential address, with ley farming as its principal theme, given at the inaugural meeting on June 20, 1945. Other contributors deal with various questions of interest in grassland management. In tests to compare different techniques for measuring grass production, a close correlation is shown between output in terms of grass clippings by the movable cage method with that from live weight increase in grazing cattle. Other grazing experiments 